\title{
Registration of 'NAROSORG2' Sorghum Variety with Desirable Farmer Attributes for Uganda
}

\author{
Charles Andiku", *, Geofrey Lubadde ${ }^{2}$, Charles John Aru ${ }^{1}$, John Emanio ${ }^{1}$, Michael Adrogu Ugen ${ }^{1}$, \\ Johnie Ebiyau ${ }^{1}$
}

${ }^{1}$ National Semi-Arid Resources Research Institute (NaSARRI), Soroti, Uganda

${ }^{2}$ Department of Crop Production and Management, Faculty of Agriculture and Animal Sciences, Busitema University, Tororo, Uganda

\section{Email address:}

andikuc@gmail.com (C. Andiku)

${ }^{*}$ Corresponding author

\section{To cite this article:}

Charles Andiku, Geofrey Lubadde, Charles John Aru, John Emanio, Michael Adrogu Ugen, Johnie Ebiyau. Registration of 'NAROSORG2' Sorghum Variety with Desirable Farmer Attributes for Uganda. International Journal of Applied Agricultural Sciences.

Vol. 6, No. 4, 2020, pp. 76-79. doi: 10.11648/j.ijaas.20200604.14

Received: June 19, 2020; Accepted: July 3, 2020; Published: July 23, 2020

\begin{abstract}
Sorghum [Sorghum bicolor (L.) Moench] is the major cereal in Uganda that has recently evolved from being a food crop to a cash crop. However, low farm yields of less than $500 \mathrm{~kg} \mathrm{ha}^{-1}$ have been recorded due to both abiotic and biotic stresses. Consequently, NaSARRI developed NAROSORG2, released in 2017, that can withstand some of the abiotic and biotic stresses. NAROSORG2 is a derived red seeded local landrace selection (IS8193) from East Africa, advanced by the International Crops Research Institute for the Semi-Arid Tropics (ICRISAT) through repeated bulk selections for tolerance against abiotic and biotic stresses. The agronomic evaluation was carried out in Uganda for the first and second rainy seasons of 2017 and the findings indicated that NAROSORG2, out-performed the check commercial variety, SESO3 with mean grain yield of $2740 \mathrm{~kg} \mathrm{ha}^{-1}$ across the entire environment. It also recorded early days to $50 \%$ flowering of 65.23 days (early maturity variety) like the commercial check variety, SESO3 with a medium height of $165.35 \mathrm{~cm}$. NAROSORG2 has superior agronomic traits of stay-green trait, resistant to bird damage due to high levels of tannins, drought, midge, and Striga tolerant, good for food, and local brew. Therefore, it will supplement other released varieties in contributing to food security and poverty alleviation among the rural communities in Uganda.
\end{abstract}

Keywords: Variety Registration, NAROSORG2, Evaluation and Genotypes

\section{Introduction}

Sorghum [Sorghum bicolor (L.) Moench] is the major cereal crop in Uganda after maize and rice. It's mainly grown by the rural poor and it is a staple food for the foodinsecure rural communities [4] in Uganda. However, of recent Sorghum has increasingly become both cash and food crops for the millions of rural poor people [5] thus becoming a key crop for sustaining their livelihood. Regrettably, its production is constrained by both abiotic (poor performing varieties, acidic soils, low soil fertility, heat, drought and floods, and policy issues) and biotic factors such as insect pests, birds (mainly Quelea quelea), weeds (especially Striga) and diseases]. Insect pests include shoot fly, stem borer, sorghum midge, head bug, aphids, and armyworm) while diseases include anthracnose (Colletotrichum graminicola), leaf blight (Helminthosporium turcicum), head smut (Sporisorium reilianum), downy mildew (Sclerospora sorgi), rust (Puccinia purpurea), ergot (Claviceps africana), grain mold (Fusarium verticillioides and F. semitectum), charcoal rot and viral diseases $[7,8,10]$. These contraints has resulted into low sorghum farm yields (less than $500 \mathrm{~kg} \mathrm{ha}^{-1}$ ) coupled with poor agronomic practices in Uganda. As such, sorghum breeding research in Uganda was initiated way back in the 1930 s to 1950 s with the local germplasm collection and screening for early maturity and bird resistance [6] to address some of these production challenges. However, currently, the sorghum breeding program has extended its breeding focus to increased yield, resistance to insect pests, Striga, and diseases, drought 
tolerance, high grain quality for malt, and feed, hybrid development, and maintenance in addition to fore mentioned challenges. This recently led to release of four open-pollinated sorghum varieties namely; NAROSORG1, NAROSORG2, NAROSORG3, and NAROSORG4. A follow-up study (Andiku et al. 2019 unpublished), showed that red-grain NAROSORG2 is widely grown by many sorghum farmers in Uganda especially in the Eastern, Northern, and West Nile parts of the country particularly for food and local brewing and has high local market. NAROSORG2 is fairly high-yielding and tolerant to drought, midge, and Striga in addition to minimal bird damage due to presence of tannins. It mixes well with cassava for making local bread as well as the local brew especially among the rural communities. During our participatory variety selection study (results not presented), $80 \%$ of farmers preferred NAROSORG2 against check variety, SESO3 (33\% of farmers' responses). They based their preference on red seed color, high local market demand, and other special attributes of the crop; drought, midge, and Striga tolerance and minimal or no bird damage. NAROSORG2 is pure line variety which was sourced from International Crops Research Institute for the Semi-Arid Tropics (ICRISAT)-Nairobi and it was evaluated for multilocational adaptation and consequently released in 2017 by the National Semi-Arid Resources Research Institute (NaSARRI), Uganda for production. NAROSOG2 will contribute towards food security and poverty alleviation among the rural communities in Uganda. The main objective of this study was therefore to assess the performance of promising sorghum genotypes across the major sorghum growing areas of Uganda for possible release in the country.

\section{Material and Methods}

\subsection{Parental Lines and Pedigree Information}

NAROSORG2 is a local landrace selection (IS8193) of kafir race from East Africa which was advanced by ICRISAT. It is drought, midge, and Striga tolerant variety with bird damage resistance background. NAROSORG2 is a red seeded medium maturity variety with high levels of tannins (no or minimal grain damage by birds) and has been released in Kenya and Rwanda.

\subsection{Breeding Procedure (Progression from Breeding, Testing, and Selection Process)}

Sorghum line, IS8193 was selected from East African landrace germplasm collection by ICRISAT and developed into pure line through repeated bulk selections for drought, midge, and Striga tolerance, and reduced bird damage. The advanced IS8193 sorghum line was sourced from ICRISAT for agronomic evaluation in Uganda. The materials were evaluated for multi-locational and national performance trials for country wide adaptability after conducting on station advanced generation testing and selfing plants per line for seed increase and maintenance for three seasons at NaSARRI Then, on-farm testing was conducted across the major sorghum growing areas of the country to identify farmer preferences. Phenotypically homogeneous plants were bulked and tested in at least eight (08) locations for 2 seasons. The selection was executed for grain yield, maturity period, grain color, stay green trait (drought), midge, and Striga tolerance, and bird damage resistance, earliness, marketability, plant height, and vigor (results not presented) and subsequently released in 2017.

\subsection{Performance Evaluation}

The advanced sorghum lines were evaluated for performance in replicated on-farm trials for yield and agronomic traits for two continuous seasons of 2017 at eight trial sites of Arua, Iganga, Kitgum, Mayuge, Namutumba, Oyam, Pallisa, and Serere districts of Uganda under rainfed conditions [1]. Using randomized complete block design with three replicates, the three genotypes including SESO3 as check were planted in a plot size of $5 \mathrm{~m}$ long with four rows. The genotypes were planted at a spacing of $60 \mathrm{~cm}$ by $20 \mathrm{~cm}$ in all the trial sites All the yield and agronomic data were collected from the middle two rows of the plots. During the evaluation, no fertilizer nutrient was added. The grain yield data was first collected per plot and later extrapolated into $\mathrm{Kg} \mathrm{ha}^{-1}$ to establish grain yield per hectare [1].

\subsection{Seed Maintenance and Increase}

The seed maintenance of NAROSORG2 commenced immediately after the DUS test. Both in-situ and ex-situ seed conservation methods were used. Under in-situ seed conservation, the seeds were planted on-station at NaSARRI. Before planting, the seeds were visually inspected, any damaged and off-type seed were removed. Then, two different sizes of sieves were used to discard large and smallsized seeds. NAROSORG2 was then planted in isolations separated by a distance of 500 meters from another sorghum field and few plants per line are selfed (head bagging) with a khaki paper bag and bulked to maintain the genetic purity within the line. During the growing period, the diseased plants and off types are rouged particularly at flowering and maturity phases. The harvested seeds are dressed with chemicals to control storage pests and seed-borne infections. However, under ex-situ seed conservation, the seeds were well packed in seed envelops, labeled, and stored under a controlled environment at NaSARRI and the replicates are sent to the National Centre for Genetic Resources Preservation. The stored germplasm inventory and routine storage conditions are maintained.

\subsection{Data Analysis}

Data for each observed variable were analyzed using Genstat $18^{\text {th }}$ edition and the means were separated by LSD test at 5\% level. 


\section{Results and Discussion}

\subsection{Agronomic and Plant Botanical Traits at Physiological Maturity}

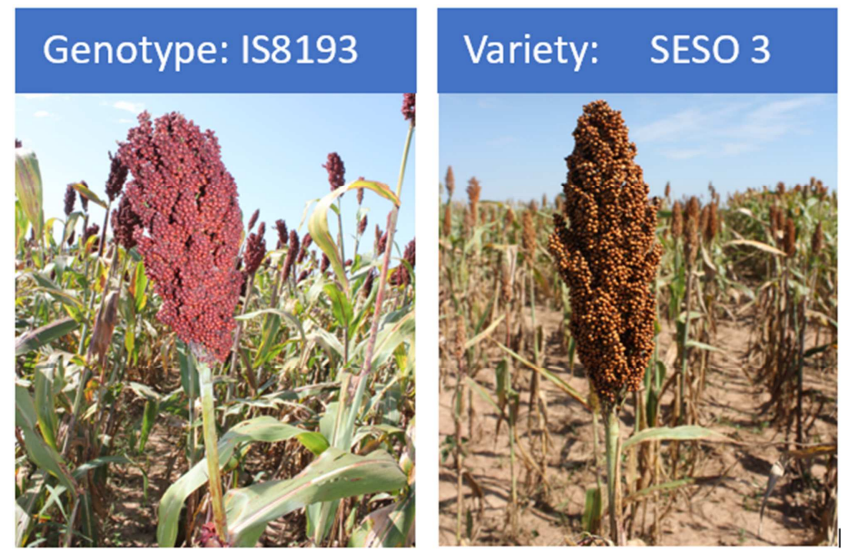

Figure 1. Panicle head of NAROSORG2 and SESO3 (Photo by U. Kyeyune).

The plant characteristics were observed and recorded according to Sorghum descriptors [3]. NAROSORG2 (IS8193) is a medium pure line red seeded sorghum (Figure 1) that does not resemble any commercial variet under production in Uganda. It has short peduncle exertion of around $2-10 \mathrm{~cm}$ between the ligule of the flag leaf and the panicle base. It also has a red-pigmented midrib with a stay- green trait (suitable for fodder) with an erect flag leaf. It is slightly taller than commercial check variety, SESO3 with drought, midge, and Striga tolerant background. NAROSORG2 is also resistant to bird damage due to high levels of tannins with yield range of 2,500 to $3,000 \mathrm{~kg} \mathrm{ha}^{-1}$ and has high threshability. It also has a semi-compact and elliptic panicle of about $20 \mathrm{~cm}$ long with $25 \%$ glume covering and the absence of awns at physiological maturity. On average, NAROSORG2 takes 65 days to flowering and 100 days to physiological maturity with plant height of 165 $\mathrm{cm}$.

\subsection{Yield and Agronomic Traits Evaluated}

The results from the analysis of variance showed that there was a highly significant difference for plant height, days to $50 \%$ flowering, and 1000-seed weight and significant difference for grain yield across all the genotypes (Table 1). There was no significant difference for genotype by environment interaction (GEI) for the traits except plant height. The absence of GEI is probably due to narrow set of genotypes used in this current study and the same trend of no GEI was noted in the previous studies by other authors where they concluded that absence of GEI in any study signifies for wide adaptability breeding and centrally screening of such targeted traits [1-2]. The average performance for the genotypes for the traits is indicated in Table 2.

Table 1. Mean square of analysis of variance of agronomic traits of three sorghum genotypes.

\begin{tabular}{|c|c|c|c|c|c|}
\hline \multirow[t]{2}{*}{ Source of variation } & \multirow{2}{*}{$\begin{array}{l}\text { Degree of } \\
\text { freedom }\end{array}$} & Grain Yield $\left(\mathrm{Kg} \mathrm{ha}^{-1}\right)$ & $\begin{array}{l}\text { 1000-Seed weight } \\
\text { (gms) }\end{array}$ & $\begin{array}{l}\text { Days to } 50 \% \text { flowering } \\
\text { (Days) }\end{array}$ & Plant height (cm) \\
\hline & & \multicolumn{4}{|l|}{ Mean Square } \\
\hline Replication & 2 & 40524 & 4.945 & 5.861 & 46.04 \\
\hline Environment & 7 & $7874645 * * *$ & $26.441 * * *$ & $68.34 * * *$ & $1128.65^{* * *}$ \\
\hline Genotype & 2 & $668230 *$ & $91.818 * * *$ & $64.007 * * *$ & $2350.63 * * *$ \\
\hline Environment $\mathrm{x}$ Genotype & 14 & $178520^{\text {ns }}$ & $1.252^{\mathrm{ns}}$ & $10.626^{\mathrm{ns}}$ & $158.77 * * *$ \\
\hline Error & 118 & 150253 & 2.331 & 7.673 & 44.68 \\
\hline
\end{tabular}

*Significant at the 0.05 level, ***Significant at 0.001 level, and ns=not significant at 0.05 level.

NAROSORG2 significantly performed better than the check commercial variety, SESO3 with a mean grain yield of $2740 \mathrm{~kg} \mathrm{ha}^{-1}$ across all the trial sites (Table 2). The NAROSORG2 had 65.23 days to $50 \%$ flowering with medium height $(165.35 \mathrm{~cm})$ which is within the early maturity period for released commercial varieties in Uganda [9]. Based on these findings, NAROSORG2 was released as a pure line open pollinated variety in Uganda in 2017.

Table 2. Agronomic traits performance of sorghum genotypes across eight locations.

\begin{tabular}{|c|c|c|c|c|}
\hline \multirow{2}{*}{ Cultivar } & Yield & 1000-Seed weight & Days to $50 \%$ flowering & Plant height \\
\hline & Kg/ha & Gms & Days & $\mathrm{Cm}$ \\
\hline NAROSORG2 & 2740 & 22.54 & 65.23 & 165.35 \\
\hline GE17/1/2013A & 2544 & 20.01 & 62.96 & 152.1 \\
\hline SESO3 (Check) & 2528 & 20.3 & 64.46 & 154.83 \\
\hline Mean & 2604 & 20.95 & 64.22 & 157.43 \\
\hline $\operatorname{LSD}(0.05)$ & $156.7^{*}$ & $0.617 * * *$ & $1.12 * * *$ & $2.702 * * *$ \\
\hline $\mathrm{Se}$ & 55.9 & 0.22 & 0.4 & 0.965 \\
\hline
\end{tabular}

*Significant at the 0.05 level, and ***Significant at 0.001 level.

\subsection{Seed Availability}

The seeds of NAROSORG2 have been deposited in the National Centre for Plant Genetic Resources Preservation and some small quantities have been kept and foundation seed multiplication done at NaSARRI, P. O. Box 56 Soroti, Uganda for research purposes. The breeders seeds is maintained by NaSARRI and small quantities of 
NAROSORG2 foundation seeds can be accessed freely for research purposes however special recognition should be accorded to the National Agricultural Research Institute (NARO) in case of new scientific discoveries.

\section{Conclusions}

NAROSORG2 significantly performed better than the check commercial variety, SESO3 across the entire trial sites in this study. Therefore, it was adapted to a diverse test environment. NAROSORG2 is a red seeded medium maturity variety with drought, midge, and Striga tolerant and bird damage resistant background. NAROSORG2 was released as a pure line open pollinated variety for production for all the major sorghum growing areas of Uganda and other similar agro-ecologies. Based on its unique attributes, NAROSOG2 will contribute towards food security and poverty alleviation among the rural communities in Uganda.

\section{Acknowledgements}

This work is the output of Harnessing Opportunities for Productivity Enhancement of Sorghum and Millets II (HOPE II), Alliance for a Green Revolution in Africa (AGRA), and Agricultural Technology and Agribusiness Advisory Services (ATAAS) funded Projects.

\section{References}

[1] Andiku, Charles \& Lubadde, Geofrey \& Aru, Charles \& Ugen, Michael \& Ebiyau, Johnie. (2020). Additive Main Effects and Multiplicative Interaction and Genotype Main Effect and Genotype by Environment Interaction Effects-Biplot Analysis of Sorghum Grain Yield in Uganda. Journal of Agricultural Science. 12. 98. 10.5539/jas.v12n6p98.
[2] Andiku, C., Tukamuhabwa, P., Ssebuliba, J. M., Talwana, H., Tumwegamire, S., \& Gruneberg, W. (2019). Evaluation of the American yam bean (Pachyrhizus spp.) for storage root yield across varying eco-geographic conditions in Uganda. doi: https://doi.org/10.5539/jas.v11n8p100

[3] IBPGR, I. (1993). Descriptors for sorghum [Sorghum bicolor (L.) Moench]. International Board for Plant Genetic Resources, Rome, Italy.

[4] Kumar, A. A., Reddy, B. V., Ramaiah, B., Sahrawat, K. L., \& Pfeiffer, W. H. J. F. C. R. (2013). Gene effects and heterosis for grain iron and zinc concentration in sorghum [Sorghum bicolor (L.) Moench]. 146, 86-95.

[5] Lubadde, G., J. Ebiyau, J. C. Aru, C. Andiku, J. A. Wandulu, M. A. Ugen. 2019. SORGHUM PRODUCTION HANDBOOK FOR UGANDA. pp 37. National Semi Arid Resources Research Institute of the National Agricultural Research Organisation (NaSARRI-NARO), Uganda.

[6] Obilana, A. (2004). Sorghum breeding research in Africa. Sorghum genetic enhancement: research process, dissemination and impacts. Patancheru 502 324, Andhra Pradesh, India: International Crops Research Institute for the Semi-Arid Tropics. 320 pp, 105.

[7] Orr, A., Mwema, C., Gierend, A., \& Nedumaran, S. (2016). Sorghum and Millets in Eastern and Southern Africa: Facts, Trends and Outlook.

[8] Reddy, B. V. S., Rao, P., Deb, U. K., Stenhouse, J. W., Ramaiah, B., \& Ortiz, R. (2004). Global sorghum genetic enhancement processes at ICRISAT. Sorghum genetic enhancement: research process, dissemination and impacts, 1 , 64-101.

[9] Robert, O. J. (2013). Genetic analysis of Striga hermonthica resistance in Sorghum (Sorghum bicolor) genotypes in Eastern Uganda (Doctoral dissertation).

[10] Wortmann, C., Mamo, M., Abebe, G., Mburu, C., Letayo, E., \& Xerinda, S. J. U. o. N. (2007). Yield Constraints of Grain Sorghum in Eastern Africa. 279 (33), 68583-60915. 